\title{
Screening of Varieties/ Breeding Materials for Resistance to Different Diseases in Natural Condition under South Gujarat Region, India
}

\author{
Prashant B. Sandipan*, G.R. Bhanderi, R.D. Patel, D.M. Patel and B.G. Solanki \\ Main Cotton Research Station (MCRS), Navsari Agricultural University (NAU), \\ Surat 395 007, Gujarat, India \\ *Corresponding author
}

\section{A B S T R A C T}

\begin{tabular}{|l|}
\hline Ke y w o r d s \\
Cotton, Screening, \\
Bacterial leaf blight, \\
Alternaria, \\
Diseases, \\
Resistance. \\
\hline Article Info \\
\hline $\begin{array}{l}\text { Accepted: } \\
\text { 19 July 2017 } \\
\text { Available Online: } \\
\text { 10 September } 2017\end{array}$
\end{tabular}

\section{Keywords}

Cotton, Screening,

Bacterial leaf blight,

Alternaria,

10 September 2017
Cotton is one of the principal commercial crop and it is the back bone of national economy of our country. Cotton remains the most miraculous fiber and is still nature's wonder fiber. Cotton is grown all around the globe, and is traded internationally as well. The production is influenced by the repeated out breaks of pest and diseases and these are the major factors responsible for lower yield of cotton in India. A field trial was conducted at Main Cotton Research Station (MCRS), NAU, Surat in the year 2015 for a season to determine the influence of different diseases in respect to different varieties/ entries. During the season, entries were evaluated for their reaction against the different diseases in cotton crop. Total thirty nine entries including the checks were evaluated for their reaction against the different diseases. Out of these entries, twenty five entries were observed disease free whereas, six entries as resistant, six entries as moderately resistant and two entries i.e. GBHV-170 and GSHV-185 observed in the Grade 3 against the bacterial leaf blight disease with 12.5 and $11.5 \%$ per cent disease intensity (PDI). Whereas, for Alternaria leaf spot disease, twenty one entries as disease free, sixteen entries as resistant and two entries as moderately resistant against the disease.

\section{Introduction}

Cotton is a natural fibre as well as White Gold enriches with soft, fluffy staple fiber that grows in a boll, or protective case, around the seeds of the cotton plant. The fiber is almost pure cellulose. The plant is a shrub native to tropical and subtropical regions around the world, including the Americas, Africa, and India.

Cotton is a white fibrous agricultural product that has a wide variety of uses, from textile production, to creating paper, to producing oil and food products. Cotton is grown all around the globe, and is traded internationally as well. Higher production of cotton requires high investment in terms of fertilizers, pesticides, weedicides and other cultural operations. This ultimately sometimes leads to or influenced by the repeated out breaks of pest and diseases and occasionally responsible for lower yield of cotton. Out of 30 diseases known to occur in cotton crop from time to time, the bacterial blight is the most wide spread and destructive disease reported to cause yield losses of about 10 to 30 per cent (Bhatti and Bhutta, 1983, Kalpana et al., 2004, Sekhon et al., 2008 and Sandipan et al., 2016) and also affect the quality of lint 
(Sharma and Chauhan, 1985). Bacterial leaf blight, boll rots, wilts and leaf spots are the most destructive cotton diseases (Chopra, 1977). Under natural, bacterial blight infection, boll yield losses up to $35 \%$ have been reported (Sheo Raj and Verma, 1988). Leaf spots rank third among the diseases on cotton in India. Among the leaf spots, bacterial blight (Xanthomonas campestris pv. malvacearum (Smith), Alternaria leaf spot (Alternaria macrospora Zimn) and grey mildew (Ramularia aereola) have been reported to be damaging. Bacterial leaf blight (BLB) of cotton caused by Xanthomonas campestris pv. malvacearum (Smith) Dye affects the entire aerial parts of cotton plant i.e. necrosis of parenchymatous tissue in the local phase and blockage of xylem vessels in its systemic phase (Casson et al., 1977). In north India, the cotton leaf curl virus disease (CLCuD) caused by a Gemini virus and transmitted by whitefly, Bemisia tabaci has become a major threat to cotton cultivation since its appearance in 1993 (Monga et al., 2011). Seed is the costliest input and is highly prone to losses in germination and vigour due to seed mycoflora. Seeds acts as carrier in transmission of pathogens and thereby causes economic threat to cotton cultivation. Resistant varieties are the valid option in any disease management strategies. Considering this whole scenario, this present investigation was made to ascertain the spectrum of fungal flora associated with the seeds of cotton.

\section{Agro meteorological condition of MCRS, Surat}

Regular monsoon was started in the second week of June i.e., 11.06.2015 with $60.2 \mathrm{~mm}$ and was followed by $209.8 \mathrm{~mm}$ in third week of June which facilitated the sowing of most of experiments. In general, germination was good even though plant population was maintained by gap filling. There was dry spell in the month of June i.e., 25.06.2015 to
09.07.2015 and 30.07.2015 to 20.08.2015 which facilitates to complete necessary cultural operations. But in the third week of September, there was heavy rainfall at once i.e., $150 \mathrm{~mm}$ which fill the fields with plenty of water and water logging condition take place. With intensive effort, drainage of water was possible and crop was saved. Thereafter, there was no rain and crop was maintained by canal irrigation. There was a deficit of about 27 per cent rainfall than previous three year average precipitation. Average maximum and minimum temperature was 33.4 and $26.0{ }^{\circ} \mathrm{C}$, respectively during crop season. In majority of the experiments, second picking was completed by the December. Overall the season was moderate for the cotton crop.

\section{Materials and Methods}

The susceptible cultivar LRA - 5166 were sown after each four entry in this experiment by dibbling method with the following experimental details (Table 1). All the recommended agronomic practices were followed for raising the good crop. In each net plot of each treatment randomly tag 5 plants and score 5 lower and 5 middle leaves of each plant in terms of 0-4 grade and work out PDI as mentioned below by using 0-4 scale as given by Sheoraj, 1988 and then these grades were converted into per cent disease incidence (PDI) by using the formula given by Wheeler, 1969 (Bacterial leaf blight and Alternaria leaf spot diseases). Here, in this experiment only grades were mentioned for BLB and ALS.

No. of infected plants (Numerical grades) Disease incidence $(\%)=$---------------- x 100 No. of leaves observed x Max. Grade

For Alternaria disease, it is standard methodology of AICCIP, Cotton and similar disease scale was used by Anil, G. H. in his thesis on Studies on leaf blight of Bt cotton 
caused by Alternaria spp. in 2013 submitted to the University of Agricultural Sciences, Dharward and Hosagoudar et al., 2008ab.

\section{For, wilt disease}

Count diseased plants out of total plants assessed and work out per cent disease incidence and decide disease reaction by referring grade chart.

PDI $=\frac{\text { No of diseased plants }}{\text { No of plant assessed }}$

For wilt disease, it is standard methodology of AICCIP, Cotton.

\section{Results and Discussion}

Efforts to locate resistant sources and their utilization in resistance breeding programme are imperative to manage the diseases in the long run. Screening was therefore undertaken to evaluate a number of cotton entries against the major diseases during kharif 2015.

Total 39+01 (LC) entries of cotton were evaluated for their reaction against wilt, alternaria leaf spot, bacterial blight diseases and other diseases. The results presented in table 2 indicated that of, these entries, twenty five entries were observed disease free whereas, six entries as resistant, six entries as moderately resistant and two entries i.e. GBHV-170 and GSHV-185 observed in the Grade 3 against the bacterial blight disease with 12.5 and $11.5 \%$ PDI.

Whereas, for Alternaria leaf spot disease, twenty one entries as disease free, sixteen entries as resistant and two entries as moderately resistant against the disease. However, other diseases were not observed.

Agro meteorological condition of MCRS, Surat

\begin{tabular}{|l|c|c|c|c|c|c|c|c|c|c|}
\hline Parameters & June & July & Aug & Sept & Oct & Nov & Dec & Jan & Total & Av. \\
\hline Surat & \multicolumn{10}{|c|}{} \\
\hline Rainfall (mm) & 270.0 & 135.2 & 027.0 & 174.4 & - & - & - & - & 606.6 & - \\
\hline Rainy Days & 7.0 & 9.0 & 4.0 & 5.0 & - & - & - & - & 25.0 & - \\
\hline Max. Temp. $\left({ }^{0} \mathrm{C}\right)$ & 33.5 & 32.5 & 32.0 & 32.0 & 36.4 & 34.9 & 32.8 & - & - & 33.4 \\
\hline Min. Temp. $\left({ }^{0} \mathrm{C}\right)$ & 28.7 & 29.2 & 28.6 & 27.4 & 26.6 & 23.7 & 18.0 & - & - & 26.0 \\
\hline Morning RH \% & 77.0 & 84.0 & 88.0 & 90.0 & 79.0 & 82.0 & 70.0 & - & - & 81.4 \\
\hline Evening RH \% & 72.0 & 79.0 & 75.0 & 77.0 & 62.0 & 69.0 & 61.0 & - & - & 70.7 \\
\hline Sunshine hrs. & 4.7 & 3.7 & 3.0 & 6.1 & 6.7 & 5.8 & 7.3 & - & - & 5.3 \\
\hline
\end{tabular}

For, bacterial leaf blight (BLB) disease

\begin{tabular}{|c|l|}
\hline Score & \multicolumn{1}{c|}{ Description } \\
\hline 0 & DF= Immune, completely free from bacterial blight \\
\hline 1 & $\begin{array}{l}\mathrm{R}=\text { Resistant, nearly 1 mm in diameter, not coalescing, reddish, not } \\
\text { angular, veins free (Spots few scattered) }\end{array}$ \\
\hline 2 & $\mathrm{MR}=$ Moderately resistant, leaf area covered up to 10\% \\
\hline 3 & $\mathrm{MS}=$ Moderately susceptible, leaf area covered up to 11-20\% \\
\hline 4 & $\mathrm{~S}=$ Susceptible, leaf area covered more than $20 \%$ \\
\hline
\end{tabular}




\section{For, alternaria leaf spot (ALS) disease}

\begin{tabular}{|c|l|}
\hline Score & \multicolumn{1}{c|}{ Description } \\
\hline 0 & No infection, Completely free from the infection \\
\hline 1 & Few <2mm, scattered, brown spots, leaf area covered < 5 \\
\hline 2 & Spots bigger, 3 mm, not coalescing, brown and 6-20\% leaf area covered \\
\hline 3 & Spots 3-5 mm, irregular in shape-coalescing, 21-40 \% leaf area covered \\
\hline 4 & Spots coalescing to form bigger lesions, irregular $>40 \%$ leaf area covered \\
\hline
\end{tabular}

\section{For, wilt disease}

\begin{tabular}{|c|l|}
\hline Score & Description \\
\hline 0 & I=No infection \\
\hline 1 & R= Slight yellowing and no defoliation, $<5 \%$ wilting \\
\hline 2 & MR=Yellowing and browning of leaves, 6-15\% plants showing wilting \\
\hline 3 & $\begin{array}{l}\text { MS= Yellowing, browning and discolouration of leaves, Some leaves fall off. Of } \\
\text { late partial wilting may occur, 16-25\% plants showing wilting }\end{array}$ \\
\hline 4 & $\begin{array}{l}\text { S= In early infection seedlings wilt, adult plant show yellowing, browning and } \\
\text { dropping off of the leaves, }>25 \% \text { plants showing wilting }\end{array}$ \\
\hline
\end{tabular}

Table.1 Experiment details

\begin{tabular}{|c|c|c|c|}
\hline 1 & \multicolumn{3}{|l|}{ Details of the Experiment } \\
\hline 2 & Name of Trial & $:$ & - \\
\hline 3 & Objective & : & To find out resistant sources for different diseases \\
\hline 4 & Location & $:$ & Main Cotton Research Station, Surat \\
\hline 5 & Year of commencement & $:$ & Kharif, 2015 \\
\hline 6 & \multicolumn{3}{|l|}{ Experimental details } \\
\hline $\mathbf{a}$ & Design & : & Non replicated \\
\hline $\mathbf{b}$ & Treatment /Variety & $:$ & \\
\hline c & Replication & : & \\
\hline d & Plot size in $\mathrm{mts}$ & : & Gross: 1.2 × 3.6 , Net: 1.2 × 2.7 \\
\hline e & No. of varieties/treatment & $:$ & $39+01$ Local check \\
\hline $\mathbf{f}$ & No. of rows/plot & $:$ & Single row \\
\hline $\mathbf{g}$ & No. of dibbles/row & $:$ & 8 \\
\hline $\mathbf{h}$ & Plot size in sq. meter & $:$ & - \\
\hline $\mathbf{i}$ & Expt. area in ha. & $:$ & 0.03 \\
\hline $\mathbf{j}$ & Spacing & $:$ & $120 \times 45$ \\
\hline $\mathbf{k}$ & FYMCL/ha & $:$ & \\
\hline 1 & Fertilizer dose NPK kg/ha & $:$ & $240: 40: 00$ \\
\hline $\mathbf{m}$ & Previous crop & $:$ & - \\
\hline $\mathbf{n}$ & Date of sowing & $:$ & 23.06 .2015 \\
\hline $\mathbf{0}$ & Date of germination & $:$ & 27.06 .2015 \\
\hline $\mathbf{p}$ & Date of gap filling & $:$ & 27.07 .2015 \\
\hline$q$ & No. of plant protection & $:$ & As \& when required \\
\hline $\mathbf{r}$ & No. of irrigation & $:$ & As \& when required \\
\hline $\mathbf{s}$ & Date of harvesting & $:$ & - \\
\hline
\end{tabular}


Table. 2 Reaction of cotton varieties/cultures against different diseases at MCRS, NAU, Surat during 2015-16

\begin{tabular}{|c|c|c|c|c|c|c|c|}
\hline \multirow{2}{*}{$\begin{array}{l}\text { Sr. } \\
\text { No. }\end{array}$} & \multirow[t]{2}{*}{ Entries } & \multicolumn{3}{|c|}{ Bacterial leaf blight } & \multicolumn{3}{|c|}{ Alternaria leaf spot } \\
\hline & & PDI & Max Grade & Reaction & PDI & Max Grade & Reaction \\
\hline \multicolumn{8}{|c|}{ MLT of G. hirsutum } \\
\hline 1 & GISV-267 & 0.0 & 0 & DF & 0.0 & 0 & $\mathrm{DF}$ \\
\hline 2 & GISV-272 & 0.0 & 0 & $\mathrm{DF}$ & 0.0 & 0 & $\mathrm{DF}$ \\
\hline 3 & GSHV-159 & 0.0 & 0 & DF & 0.0 & 0 & DF \\
\hline 4 & GSHV-162 & 0.0 & 0 & DF & 0.0 & 0 & $\mathrm{DF}$ \\
\hline 5 & GJHV-514 & 0.0 & 0 & DF & 0.0 & 0 & DF \\
\hline 6 & GJHV-516 & 6.5 & 2 & MR & 0.0 & 0 & $\mathrm{DF}$ \\
\hline 7 & GBHV-170 & 12.5 & 3 & MS & 0.0 & 0 & $\mathrm{DF}$ \\
\hline 8 & GBHV-177 & 0.5 & 1 & $\mathrm{R}$ & 2.5 & 1 & $\mathrm{R}$ \\
\hline 9 & GBHV-180 & 3.5 & 2 & MR & 0.0 & 0 & $\mathrm{DF}$ \\
\hline 10 & GBHV-183 & 6.5 & 2 & MR & 6.0 & 2 & MR \\
\hline 11 & GTHV-13/7 & 5.0 & 2 & MR & 6.5 & 2 & MR \\
\hline 12 & GTHV-13/32 & 4.0 & 2 & MR & 3.0 & 1 & $\mathrm{R}$ \\
\hline \multicolumn{8}{|c|}{ LSVT of G. hirsutum } \\
\hline 13 & GISV-308 & 0.0 & 0 & $\mathrm{DF}$ & 3.5 & 1 & $\mathrm{R}$ \\
\hline 14 & GSHV-182 & 0.0 & 0 & $\mathrm{DF}$ & 4.0 & 1 & $\mathrm{R}$ \\
\hline 15 & GSHV-184 & 0.5 & 1 & $\mathrm{R}$ & 3.0 & 1 & $\mathrm{R}$ \\
\hline 16 & GSHV-185 & 11.5 & 3 & MS & 2.5 & 1 & $\mathrm{R}$ \\
\hline 17 & GJHV-473 & 0.0 & 0 & DF & 3.0 & 1 & $\mathrm{R}$ \\
\hline 18 & GJHV-477 & 0.0 & 0 & DF & 2.0 & 1 & $\mathrm{R}$ \\
\hline 19 & GJHV-518 & 6.5 & 2 & MR & 2.5 & 1 & $\mathrm{R}$ \\
\hline 20 & GJHV-523 & 0.5 & 1 & $\mathrm{R}$ & 2.0 & 1 & $\mathrm{R}$ \\
\hline 21 & GJHV-533 & 0.0 & 0 & $\mathrm{DF}$ & 0.0 & 0 & $\mathrm{DF}$ \\
\hline 22 & GBHV-184 & 0.0 & 0 & $\mathrm{DF}$ & 0.0 & 0 & $\mathrm{DF}$ \\
\hline 23 & GTHV-13/28 & 0.0 & 0 & DF & 0.0 & 0 & $\mathrm{DF}$ \\
\hline 24 & GBHV-185 & 0.5 & 1 & $\mathrm{R}$ & 4.5 & 1 & $\mathrm{R}$ \\
\hline 25 & GBHV-187 & 0.5 & 1 & $\mathrm{R}$ & 2.5 & 1 & $\mathrm{R}$ \\
\hline 26 & GBHV-193 & 0.0 & 0 & $\mathrm{DF}$ & 0.0 & 0 & $\mathrm{DF}$ \\
\hline 27 & GTHV-7/70 & 0.0 & 0 & $\mathrm{DF}$ & 0.0 & 0 & $\mathrm{DF}$ \\
\hline 28 & GTHV-10/25 & 0.0 & 0 & DF & 0.0 & 0 & $\mathrm{DF}$ \\
\hline 29 & GTHV-10/28 & 0.5 & 1 & $\mathrm{R}$ & 2.0 & 1 & $\mathrm{R}$ \\
\hline 30 & GSHV-424/10 & 0.0 & 0 & DF & 0.0 & 0 & $\mathrm{DF}$ \\
\hline 31 & GSHV-420/10 & 0.0 & 0 & DF & 0.0 & 0 & $\mathrm{DF}$ \\
\hline 32 & GSHV-453/10 & 0.0 & 0 & DF & 0.0 & 0 & DF \\
\hline 33 & GSHV-497/10 & 0.0 & 0 & DF & 0.0 & 0 & $\mathrm{DF}$ \\
\hline 34 & GBHV-296 & 0.0 & 0 & $\mathrm{DF}$ & 0.0 & 0 & $\mathrm{DF}$ \\
\hline 35 & GBHV-297 & 0.0 & 0 & DF & 0.0 & 0 & DF \\
\hline 36 & GBHV-298 & 0.0 & 0 & DF & 0.0 & 0 & DF \\
\hline 37 & GBHV-302 & 0.0 & 0 & DF & 3.0 & 1 & $\mathrm{R}$ \\
\hline 38 & G. Cot. 23 (CC) & 0.0 & 0 & DF & 2.0 & 1 & $\mathrm{R}$ \\
\hline 39 & G.N. Cot. 25 (CC) & 0.0 & 0 & $\mathrm{DF}$ & 3.5 & 1 & $\mathrm{R}$ \\
\hline
\end{tabular}




\section{Word cloud from the Introduction}

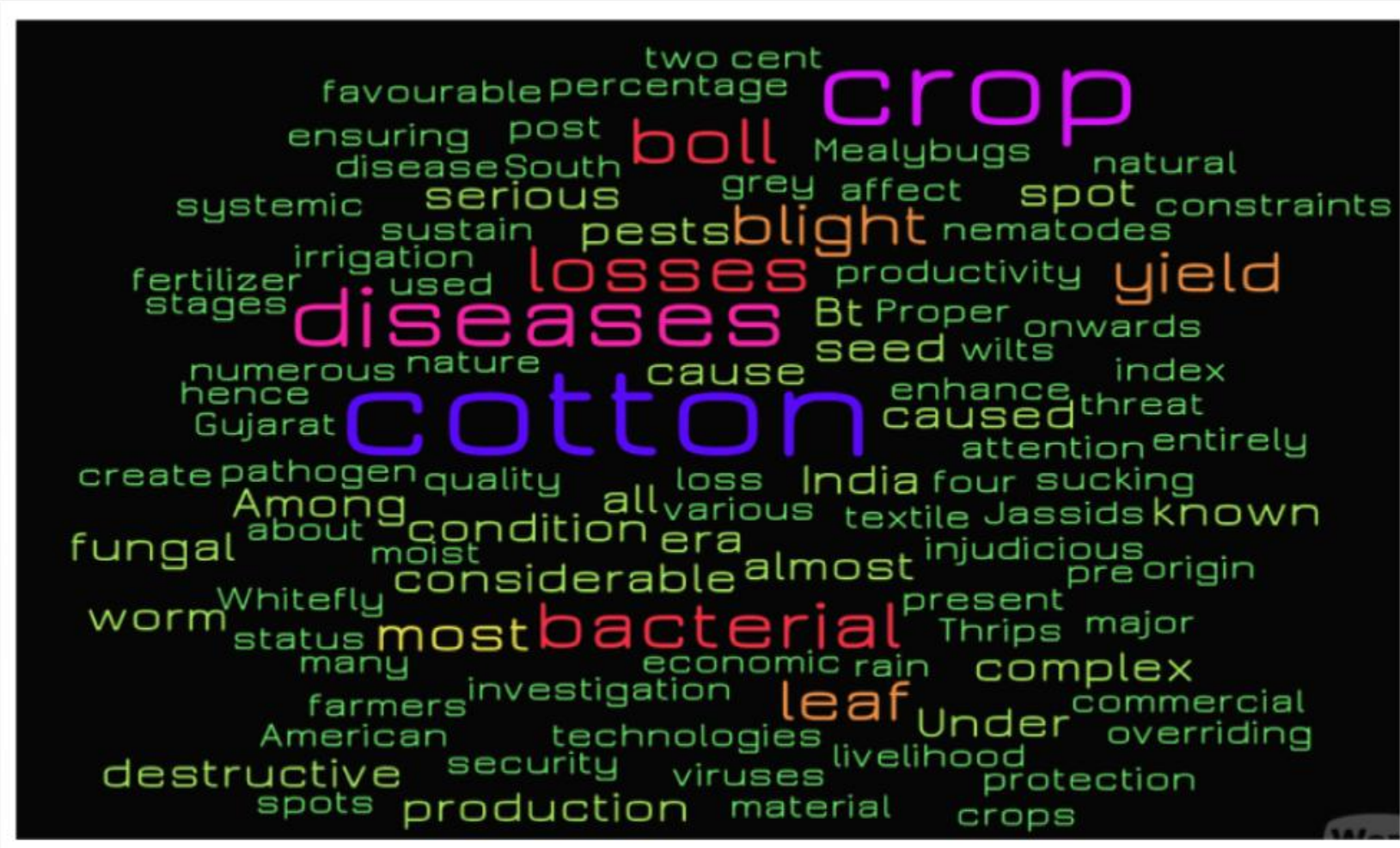

\section{Acknowledgement}

Author is highly thankful to Main Cotton Research Station (MCRS), NAU, Surat (Gujarat) for providing the required facility and other arrangements for the conducting the experiment.

\section{References}

Anil, G. H., 2013. Studies on leaf blight of Bt cotton caused by Alternaria spp. M.Sc. thesis submitted to the University of Agricultural Sciences, Dharwad.

Bhatti, M. A. R., and Bhutta, A. R. 1983. Incidence of seed borne bacterial infection in different cultivars of cotton. Pakistan Cottons, 27: 73-74.

Casson, E. T., Richardson, P. E., Brinkerhoff, L. A. and. Gholson, R. K. 1977. Histopathology of immune and susceptible cotton cultivars inoculated with Xanthomonas campestris pv. malvacearum. Phytopathology, 67: 195196.

Chopra, B. L., 1977. Important diseases of cotton and their control measures in India. Paper presented at staff course on cotton production, its processing and marketing technology held at P.A.U., Ludhiana.

Hosagoudar, G. N., Chattannavar, S. N. and Kulkarni, S. 2008a. Screening of Bt and Non Bt cotton genotypes for foliar diseases. Karnataka J. Agric. Sci., 21 (1): 141-143.

Hosagoudar, G. N., Chattannavar, S. N. and Kulkarni, S. 2008b. Survey for foliar diseases of $\mathrm{Bt}$ cotton. Karnataka $J$. Agric. Sci., 21 (1): 139-140.

Hussain, T., and Tahir, M. 1993. Chemical control of bacterial blight of cotton. Pak. J. Phytopathol. 5 (1-2): 119-121.

Kalpana, P., Chellamuthu, V. and 
Jeyalakshmi, C. 2004. Screening of cotton hybrids against bacterial blight incited by Xanthomonas campestris pv. malvacearum (Smith) Dye, Paper presented in Inter. Symp. Strat. Sust. Cotton Prod. - A Global Vision 3, Crop Production, 23-25 November 2004, Univ. Agric. Sci., Dharwad (India), pp. 373-374.

Khan, M. A., and Ilyas, M. B. 1999. Cotton germplasm response of slow blighting against Xanthomonas campestris pv. malvacearum and slow curling against $\mathrm{CLCuV}$ infection. Proc. $2^{\text {nd }}$. National Conf. of Pl. Path. Sep. 27-29, U.A.F. pp. 138-139.

Lopez-Lavalle, L.A.B., Potter N., Brubaker, C. L. 2012. Development of a rapid, accurate glasshouse bioassay for assessing fusarium wilt disease responses in cultivated Gossypium species. Plant Pathol. 61: 1112-1120.

Monga, D., Kranthi, K. R., Gopalakrishnan, N., Mayee, C. D. 2011. Changing scenario of cotton diseases in India - the challenge ahead. 2011 pp. 272-280.

Sandipan, B., Prashant, Desai H. R. and Solanki B. G. (2016). Cotton Pathology. In: Cotton Research in Gujarat, Technical Bulletin, University publication No.88/2015-16, P. 100 published by Research Scientist (Cotton), MCRS, NAU, Surat (Gujarat). Sekhon, P. S., Singh, D. and Singh, G. 2008. Cotton pathology research achievements and targets in Punjab. All India Coordinated Cotton Improvement
Project Report. PAU, Ludhiana.

Sharma, B. K., and Chauhan, M. S. 1985. Studies on the chemical control of foliar diseases of cotton in Haryana state. Agric. Sci. Digest. 5: 153-56.

Sheo Raj and Verma, J. P. 1988. Diseases of cotton in India and their management. Review of Tropical Plant Pathology, 5: 207-254.

Ulloa, M., Hutmacher, R.B., Davis, R.M., Wright, S.D., Percy, R., Marsh, B. 2006. Breeding for Fusarium wilt race 4 resistance in cotton under field and greenhouse conditions. J Cotton Sci 10: 114-127.

Wang, C., and Roberts, P. A. 2006. A Fusarium wilt resistance gene in Gossypium barbadense and its effect on root-knot nematode- wilt disease complex. Phytopathology, 96: 727-734.

Wang, P. Z., Su, L., Qin, L., Hu, B. M., Guo, W. Z. and Zhang, T. Z. 2009. Identification and molecular mapping of a Fusarium wilt resistant gene in upland cotton. Theor Appl Genet. 119:733-739.

Wheeler, B. E. J., 1969. An Introduction to Plant Disease. John Willey and Sons, London, Pp. 374.

Wiles, A. B., 1963. Comparative reactions of certain cottons to Fusarium and Verticillium wilts. Phytopathology 53:586-588.

Wu, Z. B., Li, D. B. and Chen, P. 2003. Identification of cotton resistance to Fusarium and Verticillium wilts and the influence of the diseases on yield. Acta Agron Sin, 29: 947-950.

\section{How to cite this article:}

Prashant B. Sandipan, G.R. Bhanderi, R.D. Patel, D.M. Patel and Solanki, B.G. 2017. Screening of Varieties/ Breeding Materials for Resistance to Different Diseases in Natural Condition under South Gujarat Region. Int.J.Curr.Microbiol.App.Sci. 6(9): 1355-1361. doi: https://doi.org/10.20546/ijcmas.2017.609.164 